Article

\title{
Inscribing Ethnicity: A Preliminary Analysis of Gaelic Headstone Inscriptions in Eastern Nova Scotia and Cape Breton
}

\author{
Laurie Stanley-Blackwell ${ }^{1, *}$ and Michael Linkletter ${ }^{2}$ \\ 1 Department of History, St. Francis Xavier University, Antigonish, NS B2G 2W5, Canada \\ 2 Department of Celtic Studies, St. Francis Xavier University, Antigonish, NS B2G 2W5, Canada; \\ mlinklet@stfx.ca \\ * Correspondence: lstanley@stfx.ca; Tel.: +1-902-867-3973
}

Received: 25 May 2018; Accepted: 2 August 2018; Published: 15 August 2018

\begin{abstract}
Focusing on the verbal rather than the visual elements of early and more modern headstones in eastern Nova Scotia and Cape Breton, this essay will comment on a selection of Gaelic headstone inscriptions, highlighting such elements as word choice (whether secular or religious), cemetery location, time period, and the deceased's background. Despite the striking paucity of Gaelic examples, it is our objective to discuss why Gaelic had a limited presence in Nova Scotia's pioneer Scottish immigrant cemeteries and to demonstrate how these cemeteries were contested sites, which mirrored ongoing tensions between assimilation and cultural retention. In sum, this article will assess the importance of cemeteries as material articulations of language use and language maintenance among Nova Scotia's diasporic Scots, set against the wider background of their struggles, aspirations, and shared values.
\end{abstract}

Keywords: Gaelic; cemeteries; Scottish immigrants; Nova Scotia

\section{Introduction}

The political, religious, economic, and cultural contours of Nova Scotia, Canada were profoundly shaped by the successive waves of Scottish immigrants who came to the colony during the 18th and 19th centuries. The reality of this Scottish presence is vividly epitomised by the name "Nova Scotia", which means "New Scotland" in Latin, and the provincial flag, which combines the Scottish saltire and the Royal Arms of Scotland. Despite ties between Nova Scotia and Scotland dating back to the early 17th century, Scottish influence gained prominence during the late 1700s and early 1800s, as expanding numbers of Highlanders and Lowlanders, both Roman Catholic and Presbyterian, boarded ships that plied the North Atlantic en route to the colony (Hornsby 1992, pp. 397-416). Although contemporary official immigration record keeping was notoriously unreliable, it is conservatively estimated that between 1815 and 1838, 21,833 Scottish immigrants, many of them Gaelic speakers, relocated from Scotland to Nova Scotia (Campbell and MacLean 1974, p. 22). The port community of Pictou served as the major point of entry for many of the earlier arrivals, but they soon flowed westward to Colchester and Cumberland Counties and eastward towards Antigonish and Cape Breton (pp. 35-75). In addition to confronting the physical hardships of pioneering, these Scottish immigrants faced the challenges of a power dynamic in Nova Scotia, which favoured English speakers and jeopardised cultural and linguistic identity.

Perhaps more than any other ethnic group in eastern Canada, the Scots have received a prodigious amount of historical attention, both scholarly and popular. Their impact on such facets of Nova Scotia's past as politics, economics, education, religion, literature, publishing, demography, and folk culture 
have been amply documented. However, despite their central importance in documenting and perpetuating ethnic identity, cemeteries have been an underutilised artefact for scholars researching the socio-historical context of Scottish immigration to Nova Scotia. In short, the headstones of colonial Scots, one of the most durable and ubiquitous examples of the Scottish immigration and settlement experience, have been largely overlooked by historians. This deficiency may well explain the lingering misconception that the headstones of Nova Scotia's immigrant Scots and their descendants are devoid of Gaelic inscriptions and that this group looked to other attributes, outside of the cemetery, to fortify their group identity. The following article is meant to serve as a corrective to this misreading of evidence by demonstrating to historians, linguists, folklorists, and genealogists that among Nova Scotia's Scots, there existed a small cohort who defied linguistic homogenisation and through inscriptional language preference (i.e., using Gaelic), found a way to give material expression to their culture through death.

\section{Literature Review}

In recent years, the cemetery has been identified as an important cultural landscape, rich in the artefactual evidence of text and symbol. Gravestones serve multiple functions, most notably as "tools for presentation of self and identity" (Reimers 1999, p. 164). As well, as noted by the American historian-geographer, Richard Francaviglia, these "microcosms" of the living tell us "a great deal about the living people who created them" (Francaviglia 1971, p. 509). Canadian ethnic historian, John Lehr, echoes this sentiment with his assertion that cemeteries as "fields of remembrance for the living" are as much a part of life as a part of death, "commemorating not individuals, but the society of which they were a part" (Lehr 1989, p. 8). Embodying both individual and collective identities, cemeteries offer important cultural insights into religious tenets, world views, status aspirations, funerary arts, aesthetic tastes, economic and social structures, occupational folklore, and ethnic compositions. For immigrants especially, the cemetery has been invested with a meaning that speaks directly to their sense of ethnic pride and awareness of heritage by demarcating boundaries of belonging and otherness. Among certain ethnic groups in North America, cemeteries, often the most "culturally conservative" focal point in a community, have been deemed an ideal site for forging cross-generational connections between the past, present, and future (Meyer 1993, p. 4).

In the United States, during the 1960s and 1970s, the function of the cemetery as a multivocal manifestation of identity was scrutinised closely by American scholars, such as Edwin Dethlefsen, James Deetz (Deetz and Dethlefsen 1966), and Stannard (1975, 1977). By the 1980s, a surge of interest in the concept of necroethnicity and the phenomenon of ethnic cemeteries paved the way for Terry Jordan's Texas Graveyards: A Cultural Legacy (Jordan 1982), which studied the burial attributes of three ethnic Texan cemeteries (Southern Anglo-American, Hispanic, and German), and Richard Meyer's two edited collections of essays, Cemeteries \& Grave Markers: Voices of American Culture (Meyer 1989) and Ethnicity and the American Cemetery (Meyer 1993). The latter's works, still regarded as classics, spotlight the broader significance of group identity within commemoration behaviour. In his introduction to Ethnicity and the American Cemetery, Meyer asserts: "Collectively, America's ethnic cemeteries represent largely untapped resources for the study of evolving patterns of ethnicity in American culture" (p. 3).

With this broadened perspective, gravestone studies in the United States opened the door in the 1980s, and onward, to studying the burial customs, cemetery forms, and marker types of indigenous and immigrant peoples, ranging from Native Americans to Eastern Europeans, Gypsies, and Asians, groups who were typically omitted in the "mainstream studies of American life" (ibid., p. 4). In the metal cruciform markers of German and Russian immigrants, the Feng Shui designs of Chinese cemeteries in Hawaii and the Pacific Northwest, the distinctive graves of Navajo, Mormons, and Zuni in New Mexico, and the elaborate graveside decorations in Mexican-American cemeteries in Texas, could be found evidence that many cemeteries throughout the United States diverged from "the ideal of a unified garden", which allegedly subsumed in death the differences of "those who lived separately in life" (Matturri 1993, p. 31). In recent decades, the interest in American cemeteries, as laboratories for studying observable patterns of ethnicity, has continued unabated, among established academics 
and graduate students alike, closely examining foreign language epitaphs, relationship wording, siting, and marker styles to extrapolate the meanings of ethnicity and acculturation (Broce 1996; Harnois 2000; Chung and Wegars 2005; Mallois and Caterino 2007; Bruner 2007; VanDam 2007; Gradwohl 2007; Rainville 2009; Giroux 2009; Stone 2009; Cipolla 2010; Cox et al. 2010; King 2010; Patterson 2012; Baugher and Veit 2014; and Gall and Veit 2017).

Nothing comparable to this fertile body of work exists in Canadian historical literature. For example, Deborah Trask's Life How Short, Eternity How Long (Trask 1978), still regarded as an essential primer on the history of Nova Scotian cemeteries after forty years, contains a perfunctory three-sentence paragraph on what she styles as "Scottish Stones" and four paragraphs on so-called "German Stones". Conversely, Jennifer McKendry's overview of Ontario graveyards, Into the Silent Land (McKendry 2003), singles out the significance of trades, associations, nature, and religion as important categories of analysis in cemetery research; however, her discussion of ethnicity is cursory, limited largely to a passing mention of Celtic crosses. The most significant advances in the study of necroethnicity in Canada have been made by scholars, such as Medwidsky (1989), Carlson-Cumbo (1989), and Lehr (1989), who have studied the deathways and deathscapes of Canadian-Ukrainians. Their work demonstrates that through visible identifiers of ethnic affiliation such as native language and national symbolism, the headstones of Canadian-Ukrainians have served as an expressive mirror of cultural retention, as well as a metaphor for cultural transformation and a measurement of the nature and rate of acculturation. A 2012 article co-authored by Lehr and Albanski (Lehr and Albanski 2012) highlights the academic dividends inherent in exploring how groups in Canada have used cemeteries as an expression of ethnicity. Lehr and Albanski demonstrate how Polish and Ukrainian ethnic identities were imagined, expressed, and negotiated in rural southeastern Manitoba cemeteries. Historian Frances Swyripa has followed a similar interpretive trajectory, concluding that among Ukrainian settlers in Canada, burial places doubled as symbolic spaces for localised ethno-religious identity $(2003,2010)$. Recent post-graduate theses (Martin 1999; Watkins 1999; Cook 2011; Gallén 2012; Guibord 2013; Jasinski 2013; and Shirley 2016), the research mandate of the Holy Cross Historical Trust in Halifax, and the ongoing investigations of this article's authors into the death customs of Nova Scotia's Gaels testify to an accelerating interest in Canada in exploring ethnic consciousness via the cemetery.

Only in the past few years, with George Thomson's Markers article (Thomson 2013), has there been any serious attempt to unlock the meaning of Scottish immigrant cemeteries in Canada. This innovative article, which focuses exclusively on letterform analysis as a measurement for gauging the impact of Scottish ethnicity on headstones in Nova Scotia and Prince Edward Island, is highly specialised and one-dimensional. Nevertheless, it signals the need for a more expansive framework for studying cemeteries in Canada's Gàidhealtachd as an expression of Scottish immigrant identity.

\section{Discussion of Fieldwork Evidence}

Our research path for this article has taken us to 33 cemeteries in those regions most closely linked to the Scottish diaspora in Canada, such as Pictou and Antigonish Counties in eastern Nova Scotia and Victoria, Inverness, Cape Breton and Richmond Counties in Cape Breton. The demographic contours of these counties were shaped definitively by Scottish immigrants originating from the islands of Barra, South Uist, North Uist, Harris, Lewis, Eigg, and Skye, and such mainland areas as Sutherlandshire, Ross-shire, Inverness-shire, and Perthshire. By compiling a fieldwork-based inventory of Gaelic headstone inscriptions, we have chosen to focus on the cemetery as a linguistic landscape, centring on the verbal rather than visual identifiers of ethnicity. Thus far, we have identified 157 headstones, both old and modern, which feature Gaelic inscriptions. These range from a single word to a phrase to a fully bilingual inscription.

The grave markers that we have encountered range from the primitive to the sophisticated; however, whatever their form, they attest to the power of memory and of memorialising among Scottish immigrants. An example of the upper end of the scale is the exquisitely carved 1872 headstone 
of 88-year-old Archibald "The Big Bachelor" MacKinnon, whose sandstone grave marker beside Lake Ainslie is encrusted with such images as a stag, lion's head, archer's arms with bow and arrow, and boar's head with shank-bone of a deer, the latter a central symbol on the MacKinnon crest. Some markers, in contrast, are simply rough fieldstone incised with minimal biographical details, whereas others are just mute remembrances of Scottish immigrants.

These headstones open up a fruitful line of historical inquiry into whether Scottish immigrants forged emotional links with their pioneer cemeteries and whether their grave markers, as a visible stamp on the Nova Scotian landscape, represented an extension of their distinctiveness. For many Scottish immigrants in Nova Scotia, ethnic affiliation was articulated, not surprisingly, through the use of the thistle, which became a pervasive cultural symbol, albeit not consistently, in Scottish Catholic and Scottish Presbyterian cemeteries in eastern Nova Scotia and Cape Breton during the nineteenth century (Stanley-Blackwell and Linkletter 2016; MacLean 2014). The thistle motif appears in endlessly versatile patterns, sometimes paired with a bible and rosettes or a cross or crucifixion scene, symbolising a dual identity rooted in religion and Scottish ethnicity.

A significant number of Scottish immigrants also used their grave markers to reaffirm connections between the old world and the new by identifying the deceased's place of origin and forever linking them with their original home. In this practice, the Scots seem to have eclipsed other ethnic groups who came to Canada, such as the Mennonites and Ukrainians, who rarely recorded their places of birth on their headstones (Swyripa 2003, p. 50). Inscription data for the Scots who went to Australia reveal a similarly high frequency of specified origins on the headstones of Scottish immigrants (Wilkie 2015; Straw 2012). There are several possible explanations for this phenomenon. Some historians suggest that recording birthplace on a headstone expresses "alienation from the present and attachment to a faraway past", but equally credible is the theory that it represents a way for individuals "crystallizing" a new community "to identify themselves for themselves and for each other" (Swyripa 2003, p. 49).

Given its visibility as a cultural reference point and as a space used by future generations, the Scottish immigrant cemetery would have been a perfect place to record and perpetuate the Gaelic language in Nova Scotian Scottish immigrant communities. Historians of Ukrainian and Mennonite ethnicity in North America have discovered that the headstone inscriptions for these groups, who carried their culture to the grave, were originally written in German or Ukrainian. As Frances Swyripa has remarked, this custom reinforced the role of their cemeteries "as places apart from the dominant Anglo" culture, thereby making their "personal stories" inaccessible to "outsiders", especially when even the names appeared in "an unfamiliar script or alphabet" (ibid.).

Although the history of Ukrainian and Mennonite migration to Canada may not seem directly relevant to this study, there are examples drawn from other ethnic groups in Nova Scotia, which are equally illuminating. For example, Deborah Trask has identified in Lunenburg and Lunenburg County, the main locus of German settlement in Nova Scotia, twelve headstones inscribed in German that pre-date 1810. After that date, however, English language headstones became the norm among this population. According to Trask, this finding runs counter to the popular assumption that their "assimilation into the predominant English culture began immediately" (Trask 1991, p. 40). The situation among Nova Scotia's French-speaking Acadians is more complex, with huge disparities in French language use percentages throughout the province's cemeteries. For example, in Cheticamp's St. Pierre cemetery, almost $98 \%$ of the headstone inscriptions, covering the period from 1854 to 1981, are in French (Ross 2005, p. 7), whereas Tracadie Church's "Old Cemetery", with its polyethnic cross-section of Scottish, Irish, and French grave markers from 1832 to 1944, shows the reverse: almost $98 \%$ of these headstones have English inscriptions, demonstrating how fully the English language gained hegemony in Antigonish County, where Tracadie is located.

The number of Gaelic inscriptions identified thus far in our study of Nova Scotian cemeteries may sound modest, but it prompts conjecture about why some Nova Scotian Scots expressed their cultural identity through Gaelic headstone inscriptions, whereas many others did not. For example, judging from his 1885 will, Pictou County's Kenneth McDonald, a coal miner in Albion Mines, manifested 
ethno-cultural pride as he contemplated life's last rite of passage. Ironically, however, he made no specific request for a Gaelic headstone inscription, although he bequeathed his "Highland plaid" and "gaelic [sic] Bible Testament \& Psalm Book" to family members and stipulated a "decent" burial near the graves of his grandchildren (MacDonald 1885). Similarly, Pictou County's William Cameron, a West River carpenter, left explicit instructions in 1893 for the disposition of his prized Gaelic Bible but mentioned nothing about wanting a headstone in Gaelic (Cameron 1893). One also wonders why there was no Gaelic grave marker for the Caithness-born Alexander Forbes, also from Pictou County, who invoked his mother tongue on his deathbed, with the utterance: "Cha'n eagail duit s, tha Dia laidir" (paraphrase of Isaiah 41:10, Fear not, God is strong) (Forbes 1883).

The reasons underlying the use of Gaelic inscriptions in Nova Scotian cemeteries by some deceased, thereby lending themselves a defined and visible presence in death, also prompt curiosity and speculation. For example, why was the sandstone slab for Pictou County's Lydia Fraser, the wife of a MacLennan's Brook schoolmaster, carved in English, while the death of her infant son, Donald Fraser, in 1837, was commemorated in Gaelic: "Aig Dia's ro-phriseil bas a naomh" (Psalm 116:15, Precious in the sight of the Lord is the death of his saints) (Evans and Smith 1984, p. 20)? Conversely, why did the mid-19th-century headstone in New Town's Hillside Cemetery for the elderly couple, Angus and Jane Cameron, feature only two Gaelic words "BAN" (fair) and "NIG" (abbreviation for nighean, daughter)? Did this modicum of uppercase Gaelic words, framed by the carved names of the deceased, represent merely nicknames to distinguish them as individuals, or was it a more profound assertion of Highland identity in a cemetery landscape dominated by English inscriptions?

A discussion of language preference in the cemeteries of Nova Scotia's Highland immigrants, once described as a people who "live, move, and have their being in the language; indeed, they think in it and dream in it, and, if they swear, they do that also in Gaelic", is a key theme in this article (Dunn 1953, p. 149). However, prior to such a discussion, one should consider a selection of memorial inscriptions drawn from our database, focusing on such variables as word choice, cemetery location, time period, and the deceased's background. It should be noted that Gaelic transcriptions will be provided verbatim et literatim and that accent marks are typically absent in the majority of our examples.

Headstone inscriptions are, by their very nature, abbreviated snapshots of an individual's life and identity. They must distil the deceased's essence in as few characters as possible. Gaelic headstones exemplify those instances where the dictates of space and purchasing power were overridden by a deeply felt resolve that those last words, however condensed and costly, should contain some acknowledgement of Gaelic tradition. The oldest example in our inventory dates from 1829 and was erected in St. Margaret of Scotland Roman Catholic Cemetery, Antigonish County, to commemorate Mary MacDonald, wife of John MacLeod, who relocated to Arisaig parish from Parrsboro, Nova Scotia in 1801 (Figure S1, see the Supplementary Materials). Such was the profound depth of their religious devotion that they initially travelled the vast distance to Arisaig to perform their Easter duties and to baptize their first son, William B. MacLeod, who later became the "first native-born priest" of the Diocese of Arichat (later Antigonish) and the first of the descendants of the pioneer Scots to be ordained (Cameron 1996, p. 30). Mary's remarkable headstone, erected as an act of filial piety by her priest-son, William, bears a partially Gaelic inscription, as well as a striking array of motifs, including two trumpeting angels, two thistles, a crucifix, a rosebud, a heart, and an unusual rebus. Angus "Pioneer" MacDonald, sometimes known as Angus Gillis MacDonald, who became one of Merigomish Harbour's first European settlers, was also commemorated with a Gaelic inscription on a headstone erected in St. Andrew's Cemetery, Egerton, in the 1870s, approximately 35 years after his death (Figure S2, see the Supplementary Materials). This rare individualised epitaph for this native of Morar, Inverness-shire, celebrates his legendary hospitality to the Gulf Shore's early Scottish immigrants.

Some of the offspring of Antigonish's pioneer elite also had Gaelic inscriptions on their headstones, such as Ronald "Peddler" MacDonald, a successful miller and one of the first wardens of St. Joseph's parish, who is buried in St. Joseph's Cemetery near Antigonish (Figure S3, see the Supplementary 
Materials). His parents, Angus "MacRuari" MacDonald and Mary MacDonald, were among the first wave of settlers who came from Inverness-shire to Bailey's Brook, Pictou County, in the early 1790s. Gaelic also found a niche among the more fashionable and elaborate headstones of the late 19th century. In Pictou County's Gladstone Cemetery in Four Mile Brook can be found an obelisk-style marker with a Gaelic and English inscription for local worthy, Alexander Murray, a farmer and mason, who came to Nova Scotia from Sutherlandshire in 1853, naming his farm Dunrobin after Dunrobin Castle (Figure S4, see the Supplementary Materials). In Cape Breton, an elderly Scottish-born Donald McDonald, a literate Gaelic- and English-speaking farmer in Middle River, was commemorated with a bilingual stanza, in English with a Gaelic translation, from the popular sentimental Victorian memorial poem, "The Loved One Gone Forever", while Murdoch McAulay, an octogenarian Nova-Scotian-born captain and farmer, also literate, had an impressive grave marker situated in Boularderie's Man O War Cemetery, Cape Breton, dated 1911, with a virtually all-Gaelic inscription (Figures S5 and S6, see the Supplementary Materials). In our sampling, women are far from an invisible minority. For example, in 1895, in Antigonish County's St. Andrew's Old Cemetery, 83-year-old unmarried Christy Chisholm, who emigrated from Strathglass to Nova Scotia with her parents in 1818, went to her grave with a somewhat generic Gaelic send-off "SITH DHIA [sic] DHA H-ANAM" (Peace of God to her soul), as well as a more particularised identification as "NI'N IAN DUINN" (the daughter of brown-haired John) (Figure S7, see the Supplementary Materials).

Clergy, both Catholic and Presbyterian, form a distinct subset when studying Gaelic inscriptions. Examples range from the massive monument erected by his descendants in 1903 to commemorate the legendary cleric and Gaelic poet, the Rev. James MacGregor, which includes his Gaelic tribute to his first wife, to the elegant marble column marking the 1884 Heatherton gravesite of Father William Chisholm, one-time principal of Saint Andrew's Grammar School, who served pastorates in Margaree, Cheticamp, and Heatherton and was a fluent speaker of Gaelic, English, and French (Figures S8 and S9, see the Supplementary Materials).

Another significant subset of Gaelic headstone inscriptions encompasses Gaelic-speaking tradition bearers such as John MacLean, the Rev. Alexander Maclean Sinclair, and Jonathan MacKinnon, all of whom as valiant champions of Scottish Gaeldom made an invaluable contribution to the vitality of the transnational Gaelic community (Linkletter 2006). The headstone of the Gaelic poet, John MacLean (shared with his wife, Isabella Black), enjoys an almost shrine-like status in Antigonish County's Glen Bard Cemetery, a locale once described as "no place of its kind in North America [which] better represents the culture and the spirit of the ancient Gaelic race" (Figure S10, see the Supplementary Materials) (Sinclair 1979, p. 32). His Gaelic headstone inscription offers a novel twist on the age-old entreaty "Stop, passerby". Rather than inviting reflection on human mortality, MacLean's inscription is an impassioned directive, "Cum a' Ghaidhlig suas ri d' bheo" (Keep up the Gaelic as long as you live). Nearby are the grave markers, also adorned with Gaelic inscriptions, for his children, Charles and Eliza who share a headstone, son Archibald, and eldest daughter, Christy, as well as his grandson, the Rev. Alexander Maclean Sinclair, and great grandson, the Rev. Donald Maclean Sinclair. This constellation of headstones can be termed a "dynastic burial" (Figure S11, see the Supplementary Materials). A modern-day equivalent exists in Antigonish County's Lower South River Cemetery, where several 20th-century MacPherson family headstones with Gaelic inscriptions are situated in close proximity. They are located near the burial site of Judge Hugh MacPherson, local historian and genealogist, storyteller, one-time president of Antigonish's St. Andrew's Society, and tireless promoter of Nova Scotia's Scottish heritage (Figure S12, see the Supplementary Materials). This cluster of headstones exemplifies the resurgence of interest in Gaelic language renewal, which is making an imprint on the cemetery landscape of present-day eastern Nova Scotia and Cape Breton.

The sentiments expressed in our fieldwork sample of Gaelic inscriptions are largely religious, especially among earlier markers. These include excerpts from biblical passages, such as Proverbs 31:20 "Fosgailidh i a glac do'n truaghan agus sìnidh i a làmhan [do'n fheumach]", which in the English Standard Version is as follows: "She opens her hand to the poor, and she stretches out her hands [to 
the needy]". This passage is used on at least two occasions in our inventory. It appears as a direct quotation at the bottom of the headstone of Catherine McDonald near Merigomish on the Nova Scotia mainland, whose marker declares in English, that she was wife of Peter McDonald and a native of Lochaber, Scotland, who died 22 September 1865 at the age of 71 years. Proverbs 31:20 also appears on the earliest headstone with Gaelic that we have thus far found, the marker belonging to Mary McDonald, the wife of John MacLeod, who died 22 January 1829 at the age of 55. The Gaelic inscription on Mary's grave is a personalised adaptation of the proverb. The verb tense is changed from the future (or habitual present) of the actual passage to the past tense, which is of course quite logical when used in reference to someone who has died (i.e., "Dh fhosgail i a glac do $\mathrm{n}$ truaghan agus shini a [làmhan] do n fheumach" (She opened her hand to the poor, and she stretched out her hands to the needy)). What is especially charming here is that in place of the word for hands "làmhan", an image of a minute pair of outstretched arms has been carved, now barely visible due to weathering. Mary McDonald's marker is located in Arisaig, Nova Scotia, approximately $31 \mathrm{~km}$ east of Catherine McDonald's Merigomish grave (Figure S13, see the Supplementary Materials). It may be that the two were related. Certainly, the two communities were connected through the first Highland settler in Arisaig, Angus "Pioneer" MacDonald, previously mentioned.

Angus had come initially to North America with the Glenaladale settlement, sponsored in large part by the Catholic Church and John Macdonald, Laird of Glenaladale. This migration, one of the first major Highland settlements in what is now Canada, specifically Prince Edward Island, was composed of people from South Uist and the Lochaber district. Angus was a cousin of Glenaladale and fought in the Battle of Quebec in 1775. As a reward, he was offered 500 acres of land of his choosing in eastern Nova Scotia. He initially chose a parcel of land that he called Arisaig after the land of his birth but did not stay there long and finally settled further west up the coast in Merigomish Harbour. Apparently, Angus's home became a well-known stop for many Gaels travelling from the earlier settlement of Pictou, heading east to the newer communities being established in Antigonish and Cape Breton. This hospitality is indicated in the Gaelic inscription on his headstone "Cairid na chiad Gaeil a Thainig un' Duthch'" (A friend of the first Gaels who came to the country) (Figure S14, see the Supplementary Materials). It is perhaps not surprising that reference to hospitality, such an important and central value of Gaelic society, is also a tenet represented on headstones. We also see it, for instance, on the grave of Allan and Sarah MacDonald of Iona, Cape Breton, which states, "Bho'n a bha dorus bhur taighe daonan fosgailte ri luchd siubhail, guidheamaid dorsan flathanais a bhi fosgailte reidh, ro'r n-anam" (Since your door was always open to travellers, let us pray the doors of heaven be clear and open before your soul).

The length of a particular Gaelic passage can vary according to headstone. These inscriptions run the spectrum from being completely in Gaelic, such as that for John MacLean "the Bard" (or Bàrd Thighearna Chola) already mentioned, to the very short, such as that for Alexander and Mary MacDonald of Stewartdale, Cape Breton. Their headstone includes a carving of an open Bible on the top of the stone with two Gaelic words "Tiomnadh Nuadh" (New Testament) (Figure S15, see the Supplementary Materials). The back of the headstone is inscribed with the interesting assertion that the stone was brought to the New World from Scotland, again emphasising the important connection to the homeland with the corollary that this particular monument must by extension be extra special.

The periodic occurrence of mistakes in Gaelic inscriptions may be attributed to a transcriber or carver error, who might or might not have been literate in the language, or it could have been that the client requesting the inscription did not, or was not able to, provide a completely accurate passage in Gaelic. Errors with prepositional pronouns and gender and the use of the singular versus plural forms appear especially in variations of the stock phrase "Fois dha anam" (Peace to his soul) and are found predominantly among more recent stones. It is not always clear that the deceased individual, or whoever it was who ordered the stone, was actually a Gaelic speaker, as with the grave of Lawrence S. MacDougall in Pictou County (Figure S16, see the Supplementary Materials). His headstone, possibly an homage to his ancestor, Martin "Pioneer" MacDonald who came to the Gulf Shore in the 1780s, 
has Gaelic on the front side with a nearly equivalent passage in English on the back. Whoever provided the Gaelic inscription did not get the genders quite right with, for instance, the phrase "Fois shiorruidh do a h-anam" (Eternal peace to her soul). Other examples include "Fois air anam" (Peace on his soul), instead of "Fois air an anmna" (Peace on their souls), in reference to two people sharing a headstone, and the incorrect use of the genitive of God as in "sìth Dhia" (peace of God) instead of "sìth Dhè", which appears repeatedly and may be attributed to dialect differences (Figures S17-S19, see the Supplementary Materials). Errors may be phonetically based, influenced by English spelling, as in "shinn" instead of "sinn", or errors with lenition as in "do tamh" instead of "do thàmh" or "mo graidh" instead of "mo ghràidh". Errors can also be unintentionally comical, such as the various misspellings of "fois" as "foif" and "soif", or instead of "Màthair chiùin" one sees "Nàthair chiùin", which is uncomfortably close to "nathair chiùin", meaning "gentle snake" instead of "gentle mother" (Figures S20-S25, see the Supplementary Materials).

\section{Analysis of Findings}

Our research in eastern Nova Scotia and Cape Breton demonstrates that the headstones of Scottish immigrants and their descendants tell collective, as well as individual stories, offering scholars the means to track through time via inscription samples the trajectories of Gaelic language maintenance, language loss, and language renewal. Given the supposition of widespread illiteracy among immigrant Gaels and the stigma that was sometimes attached to speaking the language, it may seem surprising to find any Gaelic on headstones at all (Dunn 1953, p. 134). Therefore, the inclusion of the language among the numbers of gravestones that we have found thus far has to be taken as a sign of a certain level of cultural confidence among those who chose to have Gaelic on their own or a loved one's headstone. Such a choice in an era of great pressure to conform to the dominant, mainstream language and culture is obviously a deliberate act. It should be interpreted as a clear indication of cultural and linguistic affiliation among our examples of 19th-century headstones, or among more recent stones, at the very least, a desire to demonstrate ethnic identity beyond the use of the more generic, nearly ubiquitous symbol of Scottish ethnicity, the thistle.

It is difficult to ascertain definitively why certain people, resistant to the effects of prejudice, chose to include Gaelic on their headstones, thereby ethnically differentiating themselves and retaining a conscious, public and permanent cultural association with their native tongue. Why did they defy the de facto memorial lexicon of the time and opt for a choice that could be styled as "marked and transgressive" (Vajta 2018, p. 146)? Is it unreasonable to characterise this response as a form of "discourse of opposition to the power in place" (ibid., p. 152)? Such questions, for which the answers remain stubbornly elusive, closely intersect with the issue of why death became a catalyst for conformist expression among so many Scottish immigrants and why they actualised their ethnic identity in a pictorial form (e.g., thistle motif), rather than with a linguistic signifier.

In answering this question, it is important to acknowledge that it is typically the survivors who choose the wording on headstones. In short, inscriptions are "culturally mediated expressions of social identity" constructed by the "family, friends and community of the deceased" (Gallén 2012, p. 6). This fact does not undermine the authenticity or utility of this artefact. In fact, inscriptional data obtained from pioneer headstones can potentially reveal how first- and second-generation immigrants "mentally" situated themselves with respect to their "old-world origins" and illuminate why some chose Gaelic to memorialise their identity, as well as their language (Swyripa 2003, p. 50; Mytum 2004, p. 147).

Our findings also point to other conclusions. For example, all-Gaelic headstone inscriptions are very much the exception. When used, Gaelic inscriptions are invariably supplemental to English text. In each of the so-called priest rows in Antigonish County, there is at least one grave marker with a Gaelic inscription. This inscription, however, has tertiary status, usually relegated to a side panel, whereas English and Latin are more prominently featured on the front of the stone. The affection that these Scottish Catholic clergy had for Gaelic cannot be gainsaid, but the multi-lingual inscription also 
served another purpose, proclaiming their learning and setting them apart from others, as did the strategic location and grandiose scale of their cemetery memorials.

Generally speaking, the 19th- and early 20th-century Gaelic inscriptions that we have inventoried were rarely personalised. In this regard, our conclusions correspond with those of linguist Gwenllian M. Awbery, whose corpora fieldwork in Welsh cemeteries has identified a preponderance of inscriptions with Biblical verses, both full and partial, which demonstrate "stability" in choice (Awbery 2007, p. 64). Nova Scotia's Scottish immigrants and first-generation descendants tended to favour scriptural passages from Psalms, Proverbs, or other books of the Old Testament such as The Book of Malachi or such New Testament texts as Matthew, Mark, John, Acts, Corinthians or Colossians. Sometimes the choice of texts was less doctrinally neutral, with such denomination-specific sources of inspiration as the Gaelic Metrical Psalter, the "Prayer for the Poor Souls in Purgatory", or Deuterocanonical texts such as Ecclesiasticus. The heavily inflected religious tone of these inscriptions is not surprising, given the centrality of religion in the lives of Nova Scotia's Scottish immigrants, both Presbyterian and Roman Catholic (Stanley 1983). As noted in Douglas Campbell and Ray MacLean's Beyond the Atlantic Roar (1974), "The church was the single most important influence in the lives of all; their acceptance of and reaction to its teachings led to religion becoming the greatest influence in the formation of the character of people in eastern Nova Scotia" (p. 228).

Although this study is only a first step in a wider analysis of deathways as communicative symbolic practices among Nova Scotia's Gaels, our research findings to date point to some additional thought-provoking insights. For example, as a category of analysis, gender was not a decisive determinant in who had a Gaelic headstone inscription. So far, we have identified a near-equal number of Gaelic headstone inscriptions for men and women (not including clergy). Furthermore, the availability of Gaelic-speaking stone carvers was not directly related to the incidence of Gaelic headstone inscriptions. Although many of the early headstones in eastern Nova Scotia and Cape Breton do not display the carver's name, only a handful such as John "Stonecutter" McIsaac of Lower South River in Antigonish County spoke Gaelic, as well as English. Many, however, were not Gaelic speakers, such as the Prince Edward Island-born John F. Morrow who carved the headstone for Angus "Pioneer" MacDonald or David Hutchison, a skilful Baddeck stone carver, who left behind a remarkable body of mortuary sculpture in 19th-century Cape Breton. Unlike gender and language, age was a significant variable. Many of the pre- 1930 headstones, bearing Gaelic inscriptions (apart from those for clergy), were generally limited to an elderly cohort usually in their 70s-90s, a demographic most likely representing the immigrant generation. The higher incidence of Gaelic inscriptions in the late 19th century may also have another explanation, for it coincides with the increase in Gaelic publishing by individuals such as Alexander Maclean Sinclair and Jonathan MacKinnon of Mac-Talla Gaelic newspaper fame, making secular Gaelic literary sources much more available in the region.

Even with this explanation, one is struck by the conspicuous absence of Gaelic inscriptions on the headstones of such celebrated Gaelic tradition bearers as the Rev. Ronald MacGillivray, known as the "Sagart Arasaig" and one of Antigonish County's preeminent seanchaidhs (storytellers); the Rev. D. B. Blair, a leading 19th-century Gaelic scholar and poet; Donald MacDonald, the celebrated catechist whose charismatic Gaelic discourses dominated Cape Breton's ceist circuit for almost 25 years; the members of the "Ridge" MacDonalds, such as Allan and his son Alexander of Lower South River, Antigonish County, who were an important family of tradition bearers stemming from the Bohuntin MacDonalds of Lochaber; or Julia MacNiven who immigrated from Tiree and was a renowned midwife in Cape Breton and wife of Dr. John Noble. She was the subject of one of the most lauded songs composed by the "Bard" John MacLean (Bàrd Thighearna Chola), "Marbhrann do Mhrs Noble", which was commissioned by Mrs. Noble's husband.

One wonders if the tiny minority of Gaelic inscriptions in eastern Nova Scotia and Cape Breton betrays a pessimism about Gaelic's viability, even among some of its most fervent exponents. According to archaeologist Harold Mytum, "The choice of a particular language for a memorial indicates a commitment to that language, a statement of affiliation and confidence that the language will continue 
and so the inscription will continue to function" (Mytum 1994, p. 260). Hypothetically, is it possible that the majority of Gaels in Nova Scotia decided that whatever the fate of their mother tongue, that their biographical details, whether name, place of birth, or dates of birth and death, were best preserved in English, so that their inscriptions could be read by all and their memory preserved for posterity? In effect, were they hedging their bets, in a bid to proclaim their success and identity and communicate their personal information in the most accessible form?

A partial explanation for this phenomenon can be found in the reality of Gaelic language shift in 19th- and 20th-century Nova Scotia. Highland immigration to this region contributed to the establishment of a large Gaelic-speaking community. For example, it is estimated that by the $1850 \mathrm{~s} 80 \%$ of the Roman Catholic population alone (just over 100,000 inhabitants) in eastern Nova Scotia and Cape Breton spoke Gaelic. (Kennedy 2002, p. 55). However, Gaelic's status was far from secure. During the mid-19th century, John Boyd, editor and publisher of Antigonish's The Casket, sounded the alarm about the inexorable march of English into the far corners of Nova Scotia: " . . we must admit that Gaelic is drawing back every day and English strengthening her foundations more and more at every turn; so that there is every appearance that she will put the poor Gaelic into a tight corner unless it gets more support than it is getting" (Dunn 1953, p. 79). Nova Scotia's state school system, implemented in the 1860s, provided no safeguards to forestall Gaelic's decline. In fact, it was complicit in minoritising the language and ensuring English's pre-eminence as the medium of instruction. According to Lori Vitale Cox, "By the turn of the century, teachers scolded and spanked their students, in order to prevent them from speaking Gaelic in schools, or even in the schoolyard" (Cox 1994, p. 25). Although Canada's 1901 census documents the existence of a still robust Gaelic-speaking demographic of approximately 50,000 Nova Scotians (Dembling 2006, p. 204), the pace of language decline accelerated with out-migration from the region to New England and western Canada with people in search of greater employment opportunities. Over the next three decades, the linguistic remnant of Gaelic speakers in Nova Scotia decreased by about half.

It comes as no surprise that the percentage of Pictou County Gaelic headstone inscriptions in our inventory is miniscule. By 1901, owing to the inroads of anglicisation, Gaelic "was wiped off the map" throughout much of Pictou County, "especially the most populous districts" (Kennedy 2002, p. 64). Despite the fact that $79 \%$ of the population at this time self-identified ethnically as Scottish, only $6 \%$ could speak the language (p. 65). Throughout the province, English was ascendant as the language of commerce, politics, and professions, a reality which was institutionally entrenched in schools and universities. The message for many Gaelic-speaking settlers was clear-English was the passport to upward mobility and conformity to "the contemporary social and cultural standards of the dominant society" (Cameron 1992, p. 57) offered pragmatic and strategic benefits. Some elite Gaels even rationalised that "the best of Highland tradition" could still be preserved without Gaelic (Kennedy 2002, p. 69), thereby inadvertently making "attempts to infuse institutions with a meaningful Gaelic presence extremely difficult" (p. 74). By the 1920s, the Gaelic language in Cape Breton, the heartland of the language in Nova Scotia, registered dramatic losses, especially in the more urbanised and industrialised areas, and from the 1930s onward, the Gaelic population was on the defensive, simultaneously shrinking and aging (p. 83).

The scarcity of Gaelic headstone inscriptions in eastern Nova Scotia and Cape Breton must be contextualised against this backdrop of language loss. It makes understandable the behaviour of those settlers, who confronting the painful contradictions of assimilation into mainstream culture and maintenance of ethnic identity, rejected the Gaelic language as the means by which to anchor the deceased "in a particular ethnic or cultural context" (Reimers, p. 164) and opted for other ways to demonstrate membership to a particular ethnic group. Perhaps, consciously or subconsciously, the priority given to English as an inscriptional language implied for some the success of the individual, and by extension, the success of the group.

The more modern headstones (post-1930s) in our inventory offer a mix of formulaic and idiosyncratic inscriptions and motifs, reflecting the rising individualism in late 20th-century mortuary 
practices. The two main loci of modern headstones with Gaelic inscriptions are Iona and Mabou, Cape Breton. Today, both communities represent important centres at the forefront of the Gaelic language revival in Nova Scotia, dedicated to restoring Gaelic's status among Scottish descendants as the parlance of everyday life rather than a heritage language. According to the Nova Scotia Gaelic Affairs Office (Gaelic Affairs Nova Scotia 2018), there are approximately 230,000 descendants of Gaelic-speaking immigrants in the province, and the current number of Gaelic speakers stands at 2000 (https://gaelic.novascotia.ca/community). Present-day Antigonish and Pictou Counties are significantly underrepresented in our dataset of modern Gaelic headstone inscriptions. There, the language has registered a minimal presence on modern headstones, clearly symptomatic of its linguistic demise in these regions. The contemporary symbols in our sampling sometimes reference the musical tradition so important to current Cape Breton culture (Figures S26-S28, see the Supplementary Materials), and texts incorporate variations of standardised Gaelic phrases, such as "Fois (or sith) Dha Anam" (Peace to his soul). Spelling is heavily influenced by Biblical tradition, unsurprisingly, and mistakes appear regularly which may be attributed to semi or complete illiteracy in the language (as with some carvers for instance). Increasingly commonplace is the practice of families employing headstones as a permanent record for documenting lineal descent from their pioneer ancestor (Figures S29 and S30, see the Supplementary Materials). This phenomenon is notably paired with the increased usage of clan crests as a means to reclaim a lost sense of uniqueness and familial connection, opting for Scottish clan affiliation rather than geographical identity (Figures S31-S33, see the Supplementary Materials).

\section{Conclusions}

In this article, we have sketched in broad strokes our preliminary findings about Gaelic language use in the cemeteries of eastern Nova Scotia and Cape Breton. It is clear that these sites offer valuable information about the dynamics of language choice in Nova Scotia and mirror the fate of the Gaelic language through time and space among Nova Scotia's Gaels and the dominance of English as a memorial language among specific minority groups. As archaeologist Mary C. Beaudry has noted, "Memorialization of the individual at death is the final opportunity for an ethnic group to acknowledge that person as a member of a community constructed out of shared experiences of cultural identity, and often, shared persecution or isolation from the dominant culture" (Beaudry 1994, p. 631). The majority of Nova Scotia's Scottish immigrants and their descendants followed the path of conformity by opting for English as the preferred mode of memorialisation. A tiny minority, however, in their final transgressive communication to the living, chose to make a statement from the grave, by inscribing their ethnicity in the language of their ancestors. They defied the norm by adding a Gaelic voice to the threnody of remembrances "calling out" to be heard in the cemeteries of Nova Scotia (Vajta 2018, p. 140).

Supplementary Materials: The following are available online at http:/ /www.mdpi.com/2313-5778/2/3/29/s1, Figures S1-S33.

Author Contributions: L.S.-B. conceived and designed the research, L.S.-B. and M.L. performed the fieldwork, M.L. prepared the translations, and L.S.-B. (as lead author) and M.L. wrote the paper.

Funding: This research was funded by an Insight Development Grant from the Social Sciences and Humanities Council of Canada (SSHRC), grant number 430-2015-01168.

Acknowledgments: The authors gratefully acknowledge the research funding of SSHRC and the editorial advice of the Guest Editor, Julie Rugg, and the anonymous reviewer. The authors also want to express their appreciation for the assistance of the Managing Editor, Allie Shi, and the photographic permissions granted by Marleen Hubley-MacDonald and the Cape Breton Genealogy and Historical Association. Thank you, as well, to John D. Blackwell and Steven Stamatopoulos for assisting with proofreading and data management, respectively. The authors are also grateful to Effie Rankin for generously sharing with us her great fund of knowledge about the Gaels of Cape Breton. And, finally, we are indebted to Margaret Mackay, Honorary Fellow, Celtic and Scottish Studies, School of Literatures, Languages and Cultures, The University of Edinburgh, for her inspiration and invaluable encouragement throughout our larger research project. 
Conflicts of Interest: The authors declare no conflict of interest.

\section{References}

Awbery, Gwenllian M. 2007. Biblical Verses in Welsh Commemorative Inscriptions. Folk Life: Journal of Ethnological Studies 46: 58-72. [CrossRef]

Baugher, Sherene, and Richard Veit. 2014. The Archaeology of American Cemeteries and Gravemarkers. Gainesville: University Press of Florida.

Beaudry, Mary C. 1994. Review of Ethnicity and the American Cemetery. The Journal of American History 81: 631-32. [CrossRef]

Broce, Gerald. 1996. Juris: An Ethnic Cemetery on the High Plains. Plains Anthropologist 41: 175-82. [CrossRef]

Bruner, David. 2007. Symbols for the Living: Synthesis, Invention and Resistance in 19th to 20th Century Mortuary Practices from Montgomery and Harris County Texas. Ph.D. thesis, Binghamton University, Binghamton, NY, USA.

Cameron, William. 1893. Last Will \& Testament. File 15W-1128C. Pictou: McCulloch Heritage Centre.

Cameron, James D. 1992. "Erasing forever the brand of social inferiority": Saint Francis Xavier University and Highland Catholicism of Eastern Nova Scotia. CCHA Historical Studies 59: 49-64.

Cameron, James D. 1996. For the People: A History of St. Francis Xavier University. Kingston/Montreal: McGill-Queen's University Press.

Campbell, Douglas F., and Raymond A. MacLean. 1974. Beyond the Atlantic Roar: A Study of the Nova Scotia Scots. Toronto: McLelland and Stewart.

Carlson-Cumbo, Enrico. 1989. Contemporary Ukrainian-Canadian Grave Markers in Urban Southern Ontario. Material History Bulletin 29: 76-80.

Chung, Sue F., and Priscilla Wegars. 2005. Chinese American Death Rituals: Respecting the Ancestors. Oxford: AltaMira Press.

Cipolla, Craig. 2010. The Dualities of Endurance: A Collaborative Historical Archaeology of Ethnogenesis at Brothertown, 1780-1810. Ph.D. thesis, Department of Anthropology, University of Pennsylvania, Philadelphia, PA, USA.

Cook, Katherine R. 2011. Deathscapes: Memory, Heritage, and Place in Cemetery History. Master's thesis, Department of Anthropology, McMaster University, Hamilton, ON, Canada.

Cox, Lori Vitale. 1994. Gaelic and the Schools in Cape Breton. Nova Scotia History Review 14: 20-40.

Cox, Grant, Alberto Giordano, and Matthew Juge. 2010. The Geography of Language Shift: A Quantitative Cemetery Study in the Texas Czech Community. Southwestern Geographer 14: 3-22.

Deetz, James, and Edwin Dethlefsen. 1966. Death's Heads, Cherubs, and Willow Trees: Experimental Archaeology in Colonial Cemeteries. American Antiquity 31: 502-10.

Dembling, Jonathan. 2006. Gaelic in Canada: New Evidence from an Old Census. In Cànan E Cultur/Language E Culture: Rannsachadh na Gàidhlig 3. Edited by Wilson McLeod, James Fraser and Anja Gunderloch. Edinburgh: Dunedin Academic Press, pp. 203-14.

Dunn, Charles W. 1953. Highland Settler: Portrait of the Scottish Gael in Nova Scotia. Toronto: University of Toronto Press.

Evans, Carol, and James Smith. 1984. Duff Cemetery: The Forgotten People. Pictou: The Advocate Printing and Publishing Company.

Forbes, Alexander. 1883. Diary of Alexander Forbes, Jr. (Unpublished Typescript). File 92-22. Pictou: McCulloch Heritage Centre.

Francaviglia, Richard V. 1971. The Cemetery as an Evolving Cultural Landscape. Annals of the Association of American Geographers 61: 501-9. [CrossRef]

Gaelic Affairs Nova Scotia. 2018. Available online: https:/ /gaelic.novascotia.ca/community (accessed on 24 May 2018).

Gall, Michael J., and Richard F. Veit, eds. 2017. Archaeologies of African American Life in the Upper Mid-Atlantic. Tuscaloosa: University of Alabama Press.

Gallén, Verna Elinor. 2012. In Silence We Remember: The Historical Archaeology of Finnish Cemeteries in Saskatchewan. Master's thesis, Department of Archaeology and Anthropology, University of Saskatchewan, Saskatoon, SK, Canada. 
Giroux, Amy. 2009. Mea Familia: Ethnic Burial Identifiers in St. Michael's Cemetery, Pensacola, Florida. Master's thesis, Department of Anthropology, University of Central Florida, Orlando, FL, USA.

Gradwohl, David. 2007. Like Tablets of the Law Thrown Down: The Colonial Jewish Burying Ground of Newport, Rhode Island. Ames: Sigler.

Guibord, Maurice C. 2013. The Evolution of Chinese Graves at Burnaby's Ocean View Cemetery: From Stigmatized Purlieu to Political Adaptations and Cultural Identity. Master's thesis, Department of History, Simon Fraser University, Burnaby, BC, Canada.

Harnois, Richard D. 2000. Gone to a Better Land: A Study of Gravestone Forms, Art and Symbolism. Master's thesis, Department of Anthropology, The College of William and Mary, Williamsburg, VA, USA.

Hornsby, Stephen. 1992. Patterns of Scottish Emigration to Canada, 1750-1870. Journal of Historical Geography 18: 397-416. [CrossRef]

Jasinski, Cassandra H. 2013. The Performance of Identity through the Design of Grave Memorials Installed between 1850-1920 [sic] in St. Peter's Roman Catholic Cemetery, Peterborough, Ontario, Canada. Master's thesis, Department of Anthropology, Trent University, Peterborough, ON, Canada.

Jordan, Terry. 1982. Texas Graveyards: A Cultural Legacy. Austin: University of Texas Press.

Kennedy, Michael. 2002. Gaelic Nova Scotia: An Economic, Cultural, and Social Impact Study. Halifax: Nova Scotia Museum.

King, Charlotte. 2010. Separated by Death and Color: The African American Cemetery of New Philadelphia, Illinois. Historical Archaeology 44: 125-37. [CrossRef]

Lehr, John C. 1989. The Ukrainian Sacred Landscape: A Metaphor of Survival and Acculturation. Material History Bulletin 29: 3-11.

Lehr, John C., and Lukasz Albanski. 2012. Identity, Integration, and Assimilation Recorded in Manitoba's Polish and Ukrainian Cemeteries. Great Plains Research 22: 3-14.

Linkletter, Michael. 2006. "Bu Dual Dha Sin" (That Was His Birthright): Gaelic Scholar Alexander Maclean Sinclair (1840-1924). Ph.D. thesis, Department of Celtic Languages and Literatures, Harvard University, Cambridge, MA, USA.

MacDonald, Kenneth. 1885. Last Will and Testament. File 15W-2429M. Pictou: McCulloch Heritage Centre.

MacLean, Hilda. 2014. Gilding the Thistle: The Amplification of Scottish Identity in Australian Cemeteries. Paper presented at Death in Scotland from the Medieval to Modern: Beliefs, Attitudes and Practices, Edinburgh, UK, January 31-February 2.

Mallois, Seth, and David Caterino. 2007. Transformations in San Diego County Gravestones and Cemeteries. Historical Archaeology 41: 50-71. [CrossRef]

Martin, Jean C. C. 1999. “In Memory of" Chelsea's Historic Cemeteries: Community Institutions from Pioneer Times to the Present. Master's thesis, Department of History, University of Ottawa, Ottawa, ON, USA.

Matturri, John. 1993. Windows in the Garden: Italian-American Memorialization and the American Cemetery. In Ethnicity and the American Cemetery. Edited by Richard E. Meyer. Bowling Green: Bowling Green State University Popular Press.

McKendry, Jennifer. 2003. Into the Silent Land: Historic Cemeteries E Graveyards in Ontario. Kingston: Jennifer McKendry.

Medwidsky, Bodhan. 1989. Ukrainian Grave Markers in East-Central Alberta. Material History Bulletin 29: 72-75.

Meyer, Richard E., ed. 1989. Cemeteries E Grave Markers: Voices of American Culture. Logan: Utah State University Press.

Meyer, Richard E., ed. 1993. Ethnicity and the American Cemetery. Bowling Green: Bowling Green State University Popular Press, pp. 1-13.

Mytum, Harold. 1994. Language as Symbol in Churchyard Monuments: The Use of Welsh in Nineteenth-and Twentieth-Century Pembrokeshire. World Archaeology 26: 252-67. [CrossRef]

Mytum, Harold. 2004. Mortuary Monuments and Burial Grounds of the Historic Period. New York: Kluwer Academic/Plenum Publishers.

Patterson, Daniel W. 2012. The True Image: Gravestone Art and the Culture of Scotch Irish Settlers in the Pennsylvania and Carolina Backcountry. Chapel Hill: University of North Carolina Press.

Rainville, Lynn. 2009. Home at Last: Mortuary Commemoration in Virginian Slave Cemeteries. Markers: Annual Journal of the Association of Gravestone Studies 26: 54-83. 
Reimers, Eva. 1999. Death and Identity: Graves and Funerals as Cultural Communication. Mortality 4: 147-66. [CrossRef]

Ross, Sally. 2005. Acadian Cemeteries in Nova Scotia: A Survey. Markers 22: 1-33.

Shirley, Kimberly D. 2016. To Die a 'Canadian': How Nineteenth-Century European Immigrants Influenced the Culture of Death in Canada. Master's thesis, Department of History, Lakehead University, Thunder Bay, ON, Canada.

Sinclair, Donald M. 1979. Some Family History. Unpublished Typescript. Nova Scotia Archives (NSA) C S90/S616. Halifax: NSA.

Stanley, Laurie. 1983. The Well-Watered Garden: The Presbyterian Church in Cape Breton, 1798-1860. Sydney: University College of Cape Breton Press.

Stanley-Blackwell, Laurie, and Michael Linkletter. 2016. Looking for Thistles in Stone Gardens: The Cemeteries of Nova Scotia's Scottish Immigrants. Paper presented at Scotland's Diasporas: A Comparative International Perspective Seminar, National Museums of Scotland, Edinburgh, UK, 25 November 2016.

Stannard, David. 1975. Death in America. Philadelphia: University of Pennsylvania Press.

Stannard, David. 1977. The Puritan Way of Death: A Study in Religion, Culture, and Social Change. New York: Oxford University Press.

Stone, Gaynell. 2009. Sacred Landscapes: Material Evidence of Ideological and Ethnic Choice in Long Island, New York Gravestones, 1680-1800. Historical Archaeology 43: 142-59. [CrossRef]

Straw, Leigh. 2012. Landscapes of the Scottish Dead: Headstones and Identity in Colonial Tasmania. Journal of Australian Colonial History 14: 89-106.

Swyripa, Frances. 2003. Ancestors, the Land, Ethno-religious Identity on the Canadian Prairies: Comparing the Mennonite and Ukrainian Legacies. Journal of Mennonite Studies 21: 43-70.

Swyripa, Frances. 2010. Storied Landscapes: Ethno-Religious Identity and the Canadian Prairies. Winnipeg: University of Manitoba Press.

Thomson, George. 2013. Lettering on Gravemakers in Nova Scotia and Prince Edward Island: Regional Variation and Scottish Influence. Markers 28: 106-33.

Trask, Deborah. 1978. Life How Short, Eternity How Long: Gravestone Carving and Carvers in Nova Scotia. Halifax: Nova Scotia Museum.

Trask, Deborah. 1991. Hier Ruhet in Gott: Germanic Gravestones in Nova Scotia. In Making Adjustments: Change and Continuity in Planter Nova Scotia, 1759-1800. Edited by Margaret Conrad. Fredericton: Acadiensis Press, pp. 140-52.

Vajta, Katerina. 2018. Gravestones speak-But in what language? Epitaphs as Mirrors of Language Shifts and Identity in Alsace. Journal of Multilingual and Multicultural Development 39: 137-54. [CrossRef]

VanDam, Kara H. 2007. A Study of Language Identity and Shift: The Calvinistic Dutch of West Michigan. Ph.D. thesis, Department of Linguistics, University of North Carolina, Chapel Hill, NC, USA.

Watkins, Meredith. 1999. The Cemetery and Cultural Memory: Montreal Region 1860 to 1900. Master's thesis, Department of Geography, McGill University, Montreal, QC, Canada.

Wilkie, Benjamin. 2015. Space, Commemoration, and Iconography: Scottish Monuments and Memorials in Australia. In Scots Under The Southern Cross: Scottish Impressions of Colonial Australia. Edited by Fred Cahir, Anne Beggs Sunter and Alison Inglis. Ballarat: Ballarat Heritage Services, pp. 157-65.

(C) 2018 by the authors. Licensee MDPI, Basel, Switzerland. This article is an open access article distributed under the terms and conditions of the Creative Commons Attribution (CC BY) license (http:/ / creativecommons.org/licenses/by/4.0/). 